\title{
İntrauterin inseminasyon uygulanan hastalarda serum vitamin D seviyesinin gebelik ile ilişkisi
}

\author{
The relationship between serum vitamin D levels and pregnancy in patients \\ undergoing intrauterine insemination
}

\author{
Cihan Kabukçu, Ümit Çabuş
}

\begin{abstract}
Özet
Amaç: İntrauterin inseminasyon, nedeni açıklanamayan infertil hastalarda ilk basamak tedavi yaklaşımıdır. Çalışmamızın amacı, intrauterin inseminasyon tedavisi uygulanan kadınların gebelik sonuçlarının, serum D vitamini seviyesi ile ilişkisini belirlemektir.

Gereç ve yöntem: İntrauterin inseminasyon uygulanan 135 hastaya ait 212 ovulasyon indüksiyonu siklusuna ait veriler değerlendirilmiştir. Çalışmaya dahil edilen tüm hastalara gonadotropinler ile ovulasyon indüksiyonunu takiben intrauterin inseminasyon yapılmıştır. Hastanın ovulasyon indüksiyonu öncesi $\mathrm{FSH}$, LH, estradiol, prolaktin, anti-müllerian hormon (AMH), TSH ve $25(\mathrm{OH}) \mathrm{D}$ vitamin seviyesi, overyan yanıtı ve gebelik sonucu incelenmiştir. Serum D vitamini seviyesine göre hastalar Grup A ( $\geq 20 \mathrm{ng} / \mathrm{mL})$ ve Grup B $(<20 \mathrm{ng} / \mathrm{mL})$ olarak değerlendirilmiştir.

Bulgular: Hastaların yaş ortalaması $29,71 \pm 4,18$ idi. Hastaların ortalama infertilite süresi $4,31 \pm 2,55$ yıldı. Toplam 212 siklus çalışmaya dahil edilmiştir. 212 siklusun ovulasyon indüksiyonunda siklus başına kullanılan ortalama gonadotropin dozu $832,0 \pm 463,8 \mathrm{IU}$, ortalama indüksiyon süresi $11,49 \pm 3,45$ gündü. Grup $A$ (vitamin $D \geq 20 \mathrm{ng} /$ $\mathrm{mL}$ ) ile Grup B (vitamin $D<20 \mathrm{ng} / \mathrm{mL}$ ) arasında yaş, infertilite süresi, vücut kitle indeksi, AMH değeri, bazal antral folikül sayısı, indüksiyon süresi, kullanılan total gonadotropin dozu, endometriyal kalınlık ölçülerinde istatistiksel olarak anlamlı fark tespit edilmedi $(p<0,05)$. Grup A'da gebelik oranı \%18,3 $(n=11)$, Grup B'de ise \%16,4 $(n=25)$ olarak bulundu $(p=0,742)$. D vitamini seviyesi ile vücut kitle indeksi, infertilite süresi, antral folikül sayısı, anti müllerian hormon, indüksiyon süresi, ve gelişen folikül sayısı arasında istatistiksel olarak anlamlı korelasyon tespit edilmedi. ROC eğrisi analizi, serum D vitamin seviyesinin gebelik prediksiyonunda faydalı olmadığını göstermiştir (AUC=0,478 $p=0,684)$.

Sonuç: Ovulasyon indüksiyonunu takiben yapılan intrauterin inseminasyon sikluslarında serum $D$ vitamini seviyesi gebelik sonucu üzerinde etkili değildir.
\end{abstract}

Anahtar kelimeler: İnfertilite, intrauterin inseminasyon, vitamin D, gebelik.

Kabukçu C, Çabuş Ü. İntrauterin inseminasyon uygulanan hastalarda serum vitamin D seviyesinin gebelik ile ilişkisi. Pam Tıp Derg 2021;14:233-341.

\begin{abstract}
Purpose: Intrauterine insemination is the first-line treatment option in unexplained infertility. This study aims to determine the relationship between pregnancy outcome of intrauterine insemination cycles with serum vitamin D levels.

Materials and methods: Data from 212 ovulation induction cycles of 135 patients undergoing IUI after ovulation induction with gonadotropins were analyzed. Serum $\mathrm{FSH}, \mathrm{LH}$, estradiol, prolactin, anti-müllerian hormone $(\mathrm{AMH}), \mathrm{TSH}$, and vitamin $25(\mathrm{OH}) \mathrm{D}$ levels, ovarian response, and pregnancy results were analyzed. Patients were evaluated as Group A $(20 \mathrm{ng} / \mathrm{mL})$ and Group B $(<20 \mathrm{ng} / \mathrm{mL})$ according to serum vitamin D level.

Results:The mean age of the patients was $29.71 \pm 4$.18. The mean duration of infertility was $4.31 \pm 2.55$ years. A total of 212 cycles were included in the study. The mean gonadotropin dose used per cycle was $832.0 \pm 463.8 \mathrm{IU}$, the mean induction time was $11.49 \pm 3.45$ days. No statistically significant difference was detected between Group A (vitamin $D \geq 20 \mathrm{ng} / \mathrm{mL}$ ) and Group $B$ (vitamin $D<20 \mathrm{ng} / \mathrm{mL}$ ) regarding age, duration of infertility, BMI, AMH, antral follicle count, induction time, total gonadotropin dose, endometrial thickness $(p<0.05)$. The pregnancy rate in Group A was 18.3\% ( $n=11)$, and $16.4 \%(n=25)$ in Group B $(p=0.742)$. No correlation was found between vitamin $\mathrm{D}$ and $\mathrm{BMI}$, duration of infertility, antral follicle number, $\mathrm{AMH}$, induction time, and the number of follicles. ROC curve analysis showed that vitamin $D$ levels are not predictive for pregnancy (AUC=0.478 $p=0.684$ ).

Conclusion: Serum vitamin D levels do not affect the pregnancy rates after IUI cycles following the ovulation induction.
\end{abstract}

Key words: Infertility, intrauterine insemination, vitamin D, pregnancy.

Cihan Kabukçu, Dr. Öğr. Üye. Pamukkale Üniversitesi, Tıp Fakültesi, Kadın Hastalıkları ve Doğum Anabilim Dalı, Denizli, Türkiye, e-posta: cihankabukcu@yahoo.com (orcid.org/0000-0003-3331-5714) (Sorumlu Yazar)

Ümit Çabuş, Dr. Öğr Üye. Pamukkale Üniversitesi, Tıp Fakültesi, Kadın Hastalıkları ve Doğum Anabilim Dalı, Denizli, Türkiye, e-posta: umitcabus@gmail.com (orcid.org/0000-0001-5478-5673) 
Kabukcu C, Cabus U. The relationship between serum vitamin D levels and pregnancy in patients undergoing intrauterine insemination. Pam Med J 2021;14:233-241.

\section{Giriş}

Intrauterin inseminasyon (IUI), açıklanamayan infertilitesi olan çiftlerin tedavisinde yaygın olarak kullanılan bir işlemdir. Diğer yardımcı üreme tekniklerine göre daha az invaziv ve kolay bir yöntem olması, intrauterin inseminasyonun infertilite tedavisinde birinci basamak tedavi seçeneği olmasını sağlar [1]. IUI, açıklanamayan infertilite, ovulatuvar disfonksiyon ve hafif erkek faktörü infertilitesi için kabul edilebilir bir gebelik oranı sunar.

D vitamini, kalsiyum-fosfat homeostazını düzenleyen ve kemik mineralizasyonunu destekleyen önemli bir steroid hormondur. D vitamini ayrıca hücre proliferasyonu, diferansiasyonu ve apoptozisinde rol alır [2]. D vitamininin steroidogenez, foliküler gelişim ve spermatogenez ile ilişkili olduğu gösterilmiştir. D vitamini reseptörü (VDR) ve D vitamini sentetazı, hem kadın hem de erkek üreme dokularında yaygın olarak tanımlanmıştır. VDR over, endometrium ve myometriumda eksprese edilir [3]. VDR'nin üreme dokularında tanımlanması, kadın üreme fizyolojisinde $\mathrm{D}$ vitamininin potansiyel bir rolü olduğunu göstermektedir [4]. Ayrıca, D vitamininin hayvanlarda ve insanlarda doğurganlığı etkilediği rapor edilmiştir $[5,6]$.

D vitamini düzeyi ile yardımcı üreme tekniklerinin sonuçlarını araştıran birçok çalışma yayınlanmıştır. Çalışmaların bazılarında D vitamininin tedavi sonuçlarını olumlu olarak etkilediği [7-10], bazı çalışmalarda ise $D$ vitamininin herhangi bir etkisinin olmadığı bildirilmiştir [11-14]. Bu nedenle, D vitamininin IVF sonrası gebelik oranları üzerine etkisi hala belirsizliğini korumaktadır [4]. Literatürde D vitamini ve IVF sonuçlarını araştıran çalışmalar olmasına rağmen, IUI ve $D$ vitamini arasındaki ilişkiyi inceleyen çalışma sayısı yetersizdir. $\mathrm{Bu}$ nedenle, çalışmamızda ovulasyon indüksiyonunu takiben IUI uygulanan hastalarda D vitamin düzeyleri ile gebelik oranı arasında ilişki olup olmadığını belirlemeyi amaçladık.

\section{Gereç ve yöntem}

01.11.2017-01.04.2020 tarihleri arasında Pamukkale Üniversitesi Tıp Fakültesi Kadın Hastalıkları ve Doğum Bölümü, Yardımcı
Üreme Teknikleri Merkezinde IUI programına alınan 135 açıklanamayan infertilite tanılı hasta retrospektif olarak değerlendirilmiştir. Tüm hastalara gonadotropin ile ovulasyon indüksiyonu yapılarak indüksiyonun sonunda IUI yapılmıştır. IUI programına dahil edilmeden önce, tüm çiftlerin temel infertilite araştırması yapıldı. Kadına ait sistemik ve jinekolojik muayene, transvajinal ultrasonografi ve histerosalpingografi yapıldı. Menstrüel siklusun üçüncü gününde $\mathrm{FSH}, \mathrm{LH}$, estradiol (E2), prolaktin, anti-müllerian hormon $(\mathrm{AMH})$, TSH ve $25(\mathrm{OH})$ D vitamin için kan örnekleri alındı. Midluteal progesteron, ovulasyonu değerlendirmek için siklusun 22.-24. günleri arasında alındı. Eşlere ait semen analizi DSÖ kriterlerine göre değerlendirildi [15]. Çalışmaya dahil olma kriterleri; 12 aydan uzun infertilite süresi, kadın yaşının 20-40 yaş arası olması, $>3 \mathrm{ng} / \mathrm{mL}$ midluteal progesteron seviyesi, bazal $\mathrm{FSH}<12 \mathrm{mIU} / \mathrm{mL}$, vücut kitle indeksi (VKi) 19$35 \mathrm{~kg} / \mathrm{m}^{2}$ olması, herhangi bir pelvik patolojinin olmaması, histerosalpingografide bilateral tubal açıklığın izlenmesi ve DSÖ kriterlerine göre normal semen parametrelerinin bulunması olarak belirlendi. Endokrin veya pelvik patolojisi, bilinen endometriozis öyküsü ve geçirilmiş pelvik cerrahisi olan, dörtten fazla foliküler gelişim gösteren hastalar ve hasta kayıtlarının incelenmesi sırasında eksik veya verisi olmayan hastalar çalışma dışı tutuldu.

Vücudun $D$ vitamini durumunu gösteren en iyi parametre serum $25(\mathrm{OH})$ vitamin $\mathrm{D}$ düzeyidir. $25(\mathrm{OH})$ vitaminin D'nin optimal düzeyi hakkında görüş birliği olmamakla birlikte, 25(OH)D vitamin düzeyi $20 \mathrm{ng} / \mathrm{mL}$ 'den düşük ise $D$ vitamini eksikliği, 21 ile $29 \mathrm{ng} / \mathrm{mL}$ arasında ise $D$ vitamini yetersizliği, $30 \mathrm{ng} / \mathrm{mL}$ 'den yüksek ise yeterli düzey olarak kabul edilmektedir [16]. Çalışmaya dahil edilen hastaların serum $25(\mathrm{OH}) \mathrm{D}$ vitamin değeri $\geq 20 \mathrm{ng} / \mathrm{mL}$ olanlar $D$ vitamini eksikliği olmayan (Grup A), $<20 \mathrm{ng} / \mathrm{mL}$ olanlar D vitamin eksikliği olan (Grup B) olarak sınıflandırıldı.

Hastalar siklusun ikinci veya üçüncü günü transvajinal ultrasonografi ile değerlendirildi, bazal hormon düzeyi, antral folikül sayısı kaydedildi. Hastanın VKI $<25 \mathrm{~kg} / \mathrm{m}^{2}$ ise $75 \mathrm{IU} /$ gün gonadotropin ile, eğer VKI $\geq 25 \mathrm{~kg} / \mathrm{m}^{2}$ ise $150 \mathrm{IU} /$ gün gonadotropin ile ovulasyon indüksiyonuna 
başlandı. Gonadotropin enjeksiyonu için r-FSH (Gonal-F® Merck, İstanbul, Türkiye), insan menapozal gonadotropin (HMG) (Merional囚, IBSA, İstanbul, Türkiye) veya ürofollitropin, (Fostimon®, IBSA, İstanbul, Türkiye) kullanıldı.

Overyan yanıt ve endometrial kalınlık transvajinal ultrasonografi ile 2 veya 3 günde bir kontrol edildi. Gonadotropin dozu overyan yanıta göre ayarlandı, indüksiyonun sekizinci veya dokuzuncu gününde lider folikül $10 \mathrm{~mm}$ 'den küçük ise gonadotropin dozu $\% 50$ artırıldı. Lider folikül çapı 18 mm'ye ulaştığında, $250 \mathrm{mcg}$ rhCG (Ovitrelle®; Merck, İstanbul, Türkiye) ile ovulasyon tetiklendi. $15 \mathrm{~mm}$ 'den daha büyük üçten fazla folikül varlığında veya siklusun 21 . gününde halen 10 mm'den büyük folikül yoksa siklus iptal edildi.

Semenin hazırlanması için, inseminasyon gününde, semen örnekleri mastürbasyon yöntemi ile, toksik olmayan steril plastik kaplara alındı. Likefaksiyon için, semen oda sıcaklığında 30 dakika bekletildi. Ejakülatın likefaksiyonunu takiben semen DSÖ yönergelerine göre makroskopik ve mikroskopik özellikler açısından değerlendirildi. Sperm hazırlama işlemi Sperm Grad ${ }^{\mathrm{TM}}$ (Vitrolife, Göteborg, İsveç) kullanılarak gradient yöntemi ile yapıldı. Spermin hazırlanmasını takiben hazırlanan numune motilite ve konsantrasyon açısından değerlendirildi.

Ovulasyonun tetiklenmesi için yapılan rhCG enjeksiyonundan 36 saat sonra tek kullanımlık inseminasyon kateteri ile IUI yapıldı. Luteal faz desteği için günde iki kez 200 mg vajinal mikronize progesteron (Progestan $®$, Kocak Farma, İstanbul, Türkiye) kullanıldı.

Hastaların hCG gününden 14 gün sonra menstruasyon kanaması başlamamışsa $\beta$-hCG testi yapıldı. $\beta$-hCG testi pozitif olan hastalar takibe alınarak iki hafta sonra transvajinal ultrasonografi için çağrıldı. Transvajinal ultrasonografide bir veya daha fazla gebelik kesesinin varlığı klinik gebelik olarak tanımlandı. Biyokimyasal gebelik, > $13 \mathrm{IU} / \mathrm{L}$ plazma $\beta$-HCG konsantrasyonu olarak, düşük, 20 haftadan önce gebelik kaybı olarak ve 20 haftayı geçen gebelik, devam eden gebelik olarak tanımlandı.

Çalışma için Pamukkale Üniversitesi Tıp Fakültesi Girişimsel Olmayan Klinik Araştırmalar
Etik Kurulu'ndan 27.10.2020 tarih ve 20/66549 karar sayısı ile yerel etik onayı alınmıştır.

Tüm istatistiksel analizler SPSS yazılımı (SPSS, versiyon, 23: IBM Corporation, Somers, NY, ABD) kullanılarak yapıldı. Analizlerde verilerin tanımlayıcı özellikleri; kategorik veriler için sayı (n) ve yüzde (\%), sayısal değişkenler için ortalama \pm standart sapma, ortanca (1.çeyrek ve 3.çeyrek) değeri olarak sunuldu. Verilerin normal dağılıma uygunluğu histogram ve Kolmogorov-Smirnoff Testi ile incelendi. İki bağımsız grubun karşılaştırılması için Mann Whitney U testi kullanıldı. Kategorik değişkenler ki-kare testiile değerlendirildi. Süreklideğişkenler arasındaki ilişkiler Spearman korelasyon analizi ile incelendi. $p<0,05$ istatistiksel olarak anlamlı kabul edildi.

\section{Bulgular}

Toplam 135 hastaya 212 siklus ovaryan stimulasyon ve IUI uygulandı. Hastaların 125 'inde $(\% 92,6)$ primer infertilite, 10'nunda $(\% 7,4)$ sekonder infertilite vardı. Hastaların ortalama infertilite süresi $4,31 \pm 2,55$ yıl (dağılım, 1-15 yıl) idi. Hastaların yaş ortalaması 29,71 \pm 4,18 (dağılım, 21-39 yıl) idi. 135 hastanın 70 'ine $(\% 51,9)$ bir, 54'üne $(\% 40,0)$ iki, 11 'ine $(\% 8,1)$ üç siklus IUI tedavisi uygulanmıştır. Hasta başına ortalama siklus sayısı 1,57 idi. 212 siklusun ovulasyon indüksiyonunda siklus başına kullanılan ortalama gonadotropin dozu $832,0 \pm 463,8 \mathrm{IU}$, ortalama indüksiyon süresi $11,49 \pm 3,45$ gündü. Siklusların 141 'inde $(\% 66,5)$ tek folikül gelişimi, 57 'sinde $(\% 26,9)$ iki folikül gelişimi, 14 'ünde $(\% 6,6) 3$ folikül gelişimi izlendi. Çalışmada incelenen 212 siklusun 36's g gebelik ile sonuçlandı (siklus başına \%17,0). Hasta başına gebelik oranı $\% 26,7$ olarak bulundu. Üç gebelik biyokimyasal $(\% 8,3)$ ve 4 gebelik $(\% 11,1)$ spontan düşük ile sonuçlandı. Gebelik başına düşük oranı \%19,4 idi. Hasta başına ve siklus başına devam eden gebelik oranı sırasıyla $\% 21,5$ ve $\% 13,7$ idi. Devam eden gebeliklerin tümünün tekiz gebelik olduğu tespit edildi.

Tedaviye alınan 212 siklus, Serum $25(\mathrm{OH}) \mathrm{D}$ vitamin değeri $\geq 20 \mathrm{ng} / \mathrm{mL}$ olan hastalar $(\mathrm{n}=60)$, (Grup A: Vitamin D eksikliği olmayan), $<20 \mathrm{ng} /$ $\mathrm{mL}$ olanlar $(\mathrm{n}=152)$ (Grup B: Vitamin D eksikliği olan) olarak sınıflandırıldı. Her iki gruptaki siklusların demografik ve temel özellikleri Tablo 1 'de gösterilmiştir. Erkek ve kadın yaşı, infertilite 
Tablo 1: Grupların demografik ve siklus özelliklerinin karşılaştırılması

\begin{tabular}{|c|c|c|c|}
\hline Kadın yaşı (yıl) & $\begin{array}{l}30,87 \pm 3,79 \\
31,00(28,25-34,00)\end{array}$ & $\begin{array}{l}29,32 \pm 4,21 \\
29,00(26,00-32,00)\end{array}$ & 0,092 \\
\hline İnfertilite süresi (yıl) & $\begin{array}{l}4,37 \pm 2,56 \\
4,00(2,12-5,75)\end{array}$ & $\begin{array}{l}4,09 \pm 2,29 \\
4,00(2,62-5,00)\end{array}$ & 0,506 \\
\hline $\begin{array}{l}\text { Primer infertilite } \\
\text { Sekonder infertilite }\end{array}$ & $\begin{array}{l}56(93,3) \\
4(6,7)\end{array}$ & $\begin{array}{l}139(91,4) \\
13(8,6)\end{array}$ & $\begin{array}{l}X^{2}=0,270 \\
0,649^{* *}\end{array}$ \\
\hline Kadına ait VKI $\left(\mathrm{kg} / \mathrm{m}^{2}\right)$ & $\begin{array}{l}24,63 \pm 6,67 \\
23,53(21,30-26,37)\end{array}$ & $\begin{array}{l}26,50 \pm 6,24 \\
25,00(22,06-30,04)\end{array}$ & 0,066 \\
\hline Bazal FSH (IU/L) & $\begin{array}{l}7,80 \pm 3,80 \\
7,23(5,83-8,61)\end{array}$ & $\begin{array}{l}6,78 \pm 2,56 \\
6,57(5,32-7,83)\end{array}$ & 0,023 \\
\hline Bazal E2 (ng/L) & $\begin{array}{l}47,23 \pm 20,56 \\
46,85(31,78-60,89)\end{array}$ & $\begin{array}{l}44,56 \pm 22,44 \\
43,39(28,06-63,65)\end{array}$ & 0,446 \\
\hline $\mathrm{AMH}(\mu \mathrm{g} / \mathrm{L})$ & $\begin{array}{l}3,96 \pm 2,89 \\
3,74(1,59-5,77)\end{array}$ & $\begin{array}{l}3,96 \pm 3,33 \\
3,21(1,60-5,73)\end{array}$ & 0,660 \\
\hline Uygulanan siklus sayısı (n) & $\begin{array}{l}1,72 \pm 0,56 \\
2,00(1,00-2,00)\end{array}$ & $\begin{array}{l}1,88 \pm 0,72 \\
2,00(1,00-2,00)\end{array}$ & 0,167 \\
\hline Toplam gonadotropin dozu (ünite) & $\begin{array}{l}782 \pm 375 \\
675(600-900)\end{array}$ & $\begin{array}{l}852 \pm 495 \\
750(600-937)\end{array}$ & 0,233 \\
\hline Lider folikül sayısı $\geq 18 \mathrm{~mm}$ & $\begin{array}{l}1,48 \pm 0,70 \\
1,0(1,0-2,0)\end{array}$ & $\begin{array}{l}1,37 \pm 0,57 \\
1,0(1,0-2,0)\end{array}$ & 0,374 \\
\hline Endometriyal kalınlık (mm) & $\begin{array}{l}10,98 \pm 1,36 \\
11,00(9,92-12,00)\end{array}$ & $\begin{array}{l}11,39 \pm 1,94 \\
11,40(10,00-13,00)\end{array}$ & 0,154 \\
\hline İnsemine edilen TPMSS (x106) & $\begin{array}{l}21,01 \pm 18,04 \\
15,00(8,00-30-00)\end{array}$ & $\begin{array}{l}22,70 \pm 19,74 \\
15,00(8,00-30-00)\end{array}$ & 0,704 \\
\hline
\end{tabular}

Grup A: $(25(\mathrm{OH})$ D vitamin $\geq 20 \mathrm{ng} / \mathrm{mL})$ - (Vitamin D Eksikliği - YOK)

Grup B: $(25(\mathrm{OH})$ D vitamin $<20 \mathrm{ng} / \mathrm{mL})$ - (Vitamin D Eksikliği - VAR)

SS: standard sapma, Ç: Çeyrekler arası aralık (\%25-\%75), VKI: Vücut kitle indeksi, AMH: antimullerian hormon,

AFC: antral folikül sayısı, TPMSS: total progresif motil sperm sayısı, $X^{2}$ : Ki-kare

* Mann-Whitney U Testi

** Ki-kare testi

$p<0,05$ istatistiksel olarak anlamlı 
süresi, bazal antral folikül sayısı (AFC), vücut kitle indeksi (VKI), bazal serum FSH ve E2 seviyeleri, AMH seviyeleri, $25(\mathrm{OH}) \mathrm{D}$ vitamini seviyesi, indüksiyon süresi, total gonadotropin dozu, gelişen folikül sayısı ve endometriyal kalınlık özetlenmiştir.

Vitamin D eksikliği olmayanlar ( $\geq 20 \mathrm{ng} / \mathrm{mL})$ ile vitamin D eksiliği olanların ( $<20 \mathrm{ng} / \mathrm{mL})$ yaşları, infertilite süreleri, vücut kitle indeksi, AMH değeri, bazal antral folikül sayısı, uygulanan siklus sayısı, indüksiyon süresi, kullanılan total gonadotropin dozu, endometriyal kalınlık ölçüleri arasında istatistiksel olarak anlamlı fark tespit edilmedi $(p<0,05)$. İki grup demografik ve klinik özellikleri açıdan benzerdi.

Sikluslar D vitamini seviyesine göre sınıflandırıldığında, Grup A'da ( $\geq 20 \mathrm{ng} / \mathrm{mL}$ ) gebelik oranı \%18,3, Grup B'de <20 ng/mL $\% 16,4$ olarak bulundu $(p=0,742)$ (Tablo 2). İki grup arasında anlamlı fark yoktu. Devam eden gebelik ve düşük oranları incelendiğinde iki grup arasında anlamlı fark tespit edilmedi $(p=0,621)$. Gebeliklerin tümü tekiz gebelikti. Ovulasyon indüksiyonu sonucunda hiçbir hastada ovaryan hiperstimulasyon sendromu (OHSS) gelişmedi.

Tablo 2. Gruplara ait IUI sonuçları

\begin{tabular}{clll}
\hline & Grup A (n=60) & Grup B $(\mathrm{n}=152)$ & p \\
\hline Gebelik (n,\%) (poz / neg) & $11(18,3) / 49(81,7)$ & $25(16,4) / 127(83,6)$ & $X^{2}=0,109$ \\
Devam eden gebelik (n,\%) & $10(16,7)$ & $19(12,5)$ & 0,742 \\
Düşük (n,\%) & $1(3,8)$ & $6(3,95)$ & $X^{2}=1,770$ \\
Çoğul gebelik (n,\%) & $0,0(0)$ & $0,0(0)$ & 0,621 \\
OHSS rate (n,\%) & $0,0(0)$ & $0,0(0)$ & - \\
\hline
\end{tabular}

Grup A: $(25(\mathrm{OH})$ D vitamin $\geq 20 \mathrm{ng} / \mathrm{mL})$ - (Vitamin D Eksikliği - YOK)

Grup B: $(25(\mathrm{OH})$ D vitamin $<20 \mathrm{ng} / \mathrm{mL})$ - (Vitamin D Eksikliği - VAR)

$\mathrm{X}^{2}$ : Ki-kare

$p<0,05$ istatistiksel olarak anlamlı

D vitamini seviyesi ile vücut kitle indeksi, infertilite süresi, antral folikül sayısı, anti müllerian hormon, indüksiyon süresi, ve folikül sayısı arasında istatistiksel olarak anlamlı ilişki yoktu (Tablo 3). Sadece hcg günü ölçülen endometriyal kalınlık ile $D$ vitamini seviyesi arasında düşük düzeyde negatif ilişki tespit edildi $\left(r_{\mathrm{s}}=-0,178, p=0,010\right)$.

Tablo 3. Vitamin D düzeyi ile hastaya ait faktörlerin Spearman korelasyon katsayıları

\begin{tabular}{lll}
\hline & \multicolumn{2}{l}{$25(\mathrm{OH})$ D vitamin $(\mathrm{ng} / \mathrm{mL})$} \\
& $r$ & $p$ \\
\hline Vücut kitle indeksi $\left(\mathrm{kg} / \mathrm{m}^{2}\right)$ & $-0,107$ & 0,121 \\
İnfertilite süresi (yıl) & 0,067 & 0,333 \\
Antral folikül sayısı & $-0,034$ & 0,620 \\
Anti müllerian hormone $(\mu \mathrm{g} / \mathrm{L})$ & 0,060 & 0,401 \\
İndüksiyon süresi (gün) & $-0,096$ & 0,164 \\
Folikül sayısı & 0,093 & 0,179 \\
Endometrial kalınlık (mm) & $-0,178$ & $\mathbf{0 , 0 1 0 *}$ \\
\hline
\end{tabular}

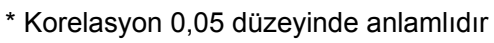


Serum D vitamini seviyesinin IUI sonras। gebelik oranı ve devam eden gebelik oranına ilişkin prediktif değeri ROC eğrisi ile analiz edilmiştir ( Şekil 1). Gebelik oranı ve devam eden gebelik oranı için, ROC eğrisinin altındaki alan sırasıyla $0,478(p=0,684)$ ve $0,515(p=0,796)$ idi. Bu değerler serum $D$ vitamin seviyesinin gebelik prediksiyonunda faydalı olmadığını göstermektedir.
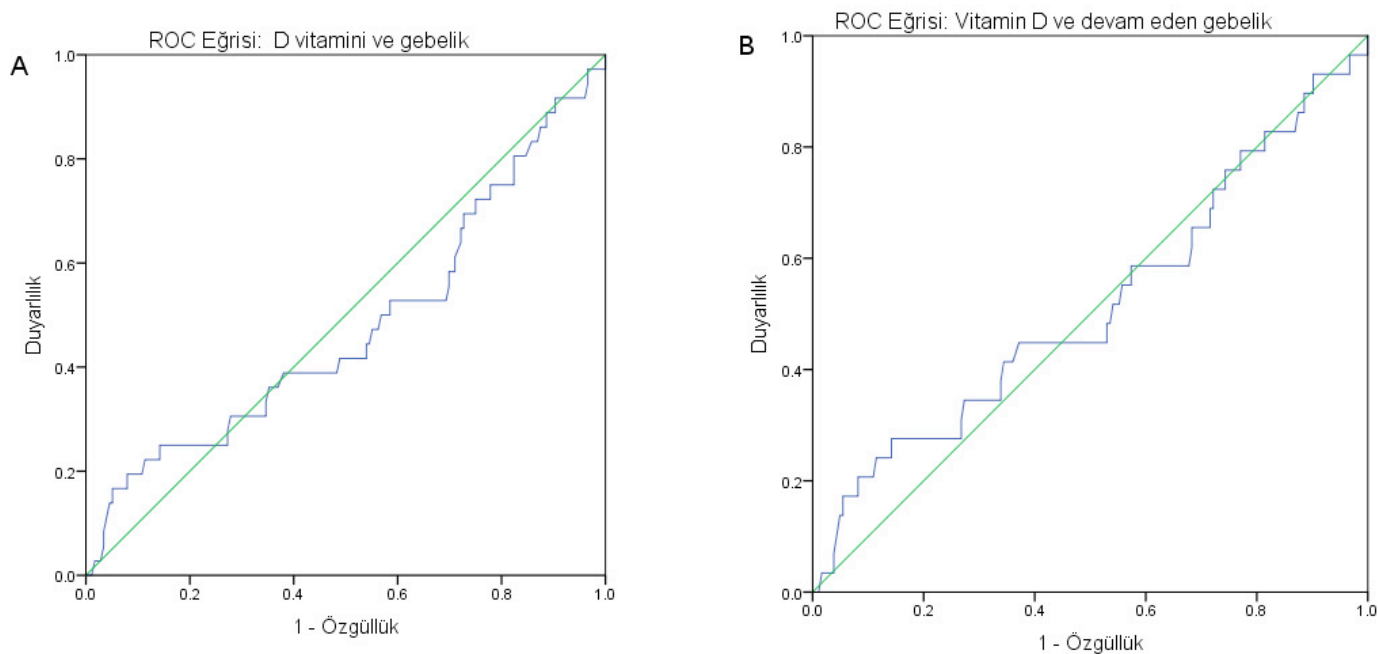

Şekil 1. Hastalarda ölçülen serum $D$ vitamini için ROC eğrisi ve performans özellikleri. A) (gebelik oranı): D vitamini için ROC eğrisinin altındaki alan 0,478 ( $p=0,684)$, B) (devam eden gebelik): D vitamini için ROC eğrisinin altındaki alan $0,515(p=0,796)$ olarak bulundu

\section{Tartışma}

$\mathrm{Bu}$ çalışmada, açıklanamayan infertilite nedeniyle ovulasyon indüksiyonunu takiben intrauterin inseminasyon uygulanan kadınlarda, serum vitamin D düzeyi ile gebelik oranı arasında herhangi bir ilişki olup olmadığını retrospektif olarak araştırdık. Çalışmanın sonuçlarına göre, intrauterin inseminasyon sonrası gebelik olan ve olmayan gruplar arasında serum vitamin $D$ seviyesinde istatistiksel olarak anlamlı bir fark bulunmadı. Çalışmaya dahil edilen hastaların çoğu D vitamini eksikliği bölgesindeydi (<20 ng/ $\mathrm{ml}$ ) ve serum vitamin $D$ seviyesinin intrauterin inseminasyon sikluslarında gebelik oranı üzerine etkisi olmadığını tespit ettik.

Vitamin D hem erkek hem de dişi üreme sisteminde önemli bir role sahiptir [17]. D vitamini reseptörü (VDR), over, endometriyum, tuba uterina, plasenta ve desidual hücrelerde bulunur ve ekspresyonu gebelik sırasında artar [18]. D vitamini, overde steroid hormonlar ve insülin benzeri büyüme faktörü bağlayıcı protein reseptörü 1'in (IGFBP-1) sentezini uyararak [19], östrojen sentezinde kilit rol oynar [5]. VDR geni nakavt edilmiş sıçanlarda uterin hipoplazinin oluştuğu ve infertilitenin geliştiği gösterilmiştir [20]. D vitamini ile kadın infertilitesi arasında ilişki olduğu rapor edilmiştir. D vitamini, foliküler gelişimi ve endometrial proliferasyonu destekler [18]. Sonuç olarak, D vitamini seviyesi reprodüktif fonksiyonlar ile ilişkili bulunmuştur [21]. IVF sonuçları ile D vitamini arasındaki ilişkiyi inceleyen birçok çalışma yapılmış olmasına rağmen literatürde $D$ vitamininin IUI sonuçları üzerine etkisini araştıran çalışmalar çok az sayıdadır.

Günümüze kadar yapılan çalışmalarda, D vitamini seviyesi ile ART sonrası klinik sonuçlar arasındaki ilişkiyi değerlendiren çok sayıda çalışma olsa da sonuçlar çelişkilidir. Bazı çalışmalar, düşük D vitamini seviyesinin, azalmış gebelik oranı ile ilişkili olduğunu göstermiştir. Buna karşılık, bazı araştırmacılar IVF / ICSI sonuçları ile vitamin D seviyesi arasında belirgin bir ilişki rapor etmemiştir [10].

Liu ve ark. [21] yaptığı çalışmada en yüksek D vitamini çeyreğinde yer alan hastaların, en düşük çeyrekte yer alan hastalar ile kıyaslandığında daha yüksek fertilizasyon oranına sahip olduğu tespit edilmiştir. Fakat aynı çalışmada D vitamini düzeyi klinik gebelik ve IVF sonrası canlı doğum oranı ile ilişkili bulunmamıştır. 
Zhao ve ark. [10] yayınladığı meta-analizde düşük D vitamininin IVF / ICSI tedavisi sonrası gebelik oranları üzerinde olumsuz etkisi olduğu gösterilmiştir. Bununla birlikte, çalışmaya dahil edilen örneklem büyüklüğünün küçük ve çalışma özellikleri farklı olması nedeniyle, D vitamini etkisini gözlemlemek ve olası etki mekanizmalarını keşfetmek için daha fazla çalışmaya intiyaç duyulduğunu belirtmiştir. Özet olarak, IVF sonucunun başarısında D vitamininin rolü hala belirsizdir.

Ovulasyon indüksiyonunu takiben IUI'ın, diğer yardımcı üreme tekniklerine göre daha ucuz, daha az invazif ve daha kolay uygulanabilmesi, onun infertilite tedavilerinde yaygın olarak kullanılan bir yöntem olmasını sağlar. IUI, açıklanamayan infertilite, ovulatuar disfonksiyon ve hafif erkek faktörü olguları için kabul edilebilir bir gebelik oranı sunar. Hasta yaşı, infertilite etiyolojisi, infertilite süresi, preovulatuar folikül sayısı, sperm parametreleri gibi birçok faktör IUI tedavisinin başarısını etkiler. Vitamin D seviyesinin de bu faktörlerden biri olabileceği hipotezi ile bu çalışmamızda serum D vitamini seviyesi ile IUI sonrası gebelik oranı arasında ilişki araştırdık. Bizim bildiğimiz kadarıyla, literatürde serum D vitamini düzeyinin IUI başarısına etkisini inceleyen tek bir çalışma vardır [22].

Yılmaz ve ark. [22] ovulasyon indüksiyonu ve IUI sonrası gebe olan ve olmayan kadınlarda serum $25(\mathrm{OH}) \mathrm{D}$ seviyeleri arasında anlamlı bir fark gözlenmediğini rapor etmiştir. Ayrıca infertilite ve $D$ vitamini arasında da anlamlı bir ilişki bulamamıştır. Benzer şekilde, biz de mevcut çalışmamızda $D$ vitamini seviyesi ile IUI sonrası gebelik oranını ilişkisiz bulduk. D vitamin seviyesi eksik ( $<20 \mathrm{ng} / \mathrm{mL}$ ) olan grupta IUI sonrası gebelik oranı \%16,4 iken D vitamin eksikliği olmayan ( $\geq 20 \mathrm{ng} / \mathrm{mL}$ ) grupta \%18,3 olarak tespit edildi. Çalışmamızda vücut kitle indeksi, infertilite süresi, antral folikül sayısı, anti müllerian hormon seviyesi, indüksiyon süresi ve gelişen folikül sayısı ile serum $D$ vitamini arasında korelasyon tespit edilmemiştir. hCG günü ölçülen endometrial kalınlık ile serum D vitamini arasında istatistiksel olarak anlamlı negatif bir ilişki vardı. Asadi ve ark. [23] yaptıkları çalışmada, IUI uygulanan PCOS'lu kadınlarda vitamin $D$ takviyesi uygulananlar ile placebo grubunu karşılaştırmışlar ve D vitamini takviyesi alanların anlamlı olarak daha kalın endometriyuma sahip olduğunu rapor etmişlerdir. Bununla birlikte, tedavi grubu ve placebo grubu arasında gebelik oranı, folikül sayısı, indüksiyon süresi ve uygulanan gonadotropin dozunda istatistiksel olarak anlamlı bir fark olmadığını belirtmişler [23].

Çalışmamıza ait bazı kısıtlılıklar dikkate alınmalıdır. Birincisi, bu çalışma geriye dönük gözlemsel bir çalışma olduğu için, sonucu etkileme potansiyeli olan faktörlerin etkisi dışlanamaz. Bununla birlikte çalışmamızdaki iki grubun demografik ve siklus özellikleri incelendiğinde, potansiyel karıştırıcı faktörler iki grup arasında istatistiksel olarak farklı değildir. İkinci kısıtlılık, çalışmamızda IUI uygulanan kadınlarda potansiyel mevsimsel değişiklikler değerlendirilmemiştir; sadece serum vitamin D seviyesi üzerinden kantitatif değerlendirmeler yapılmıştır. Çalışmamızın güçlü yönlerinden birisi geniş bir zaman dilimi içerisinde, nispeten fazla hasta ile yapılmış olmasıdır. Diğer bir güçlü yönü de, çalışmanın tek merkezde, sikluslar arasında değişmeyen standart tedavi yaklaşımı ile yapılmış olmasıdır.

Sonuç olarak; burada sunulan veriler, ovulasyon indüksiyonunu takiben yapılan intrauterin inseminasyon tedavisinde $D$ vitamini düzeylerinin gebelik sonuçlarını etkilemediğini göstermektedir. Genel sağlık için, serum D vitamini seviyesi $<20 \mathrm{ng} / \mathrm{mL}$ olanlarda $D$ vitamini takviyesi gerekli olsa da, bu takviyenin infertil çiftlerde gebelik oranlarını artırıp artırmayacağı yönünde bulgular yetersizdir. Bu nedenle, bugüne kadar yayınlanmış özellikle IVF ve D vitamini çalışmalarında da net sonuçlar bulunamamış olması nedeniyle, D vitamini ve IUI sonrası gebelik arasındaki ilişkiyi açıklayabilmek için geniş ölçekli araştırmalara intiyaç vardır.

Çıkar ilişkisi: Yazarlar çıkar ilişkisi olmadığını beyan eder.

\section{Kaynaklar}

1. Ayeleke RO, Asseler JD, Cohlen BJ, Veltman Verhulst SM. Intra-uterine insemination for unexplained subfertility. Cochrane Database Syst Rev 2020;3:CD001838. https://doi.org/10.1002/14651858. CD001838.pub6

2. Chen $\mathrm{Y}$, Zhi $\mathrm{X}$. Roles of Vitamin $\mathrm{D}$ in reproductive systems and assisted reproductive technology. Endocrinology 2020;161. https://doi.org/10.1210/ endocr/bqaa023 
3. Luk J, Torrealday S, Neal Perry G, Pal L. Relevance of vitamin D in reproduction. Hum Reprod 2012;27:30153027. https://doi.org/10.1093/humrep/des248

4. Irani M, Merhi Z. Role of vitamin D in ovarian physiology and its implication in reproduction: a systematic review. Fertil Steril 2014;102:460-468. https://doi. org/10.1016/j.fertnstert.2014.04.046

5. Kinuta K, Tanaka H, Moriwake T, Aya K, Kato S, Seino $Y$. Vitamin $D$ is an important factor in estrogen biosynthesis of both female and male gonads. Endocrinology 2000;141:1317-1324. https://doi. org/10.1210/endo.141.4.7403

6. Lerchbaum E, Rabe T. Vitamin D and female fertility. Curr Opin Obstet Gynecol 2014;26:145-150. https:// doi.org/10.1097/GC0.0000000000000065

7. Rudick B, Ingles S, Chung K, Stanczyk F, Paulson R, Bendikson K. Characterizing the influence of vitamin D levels on IVF outcomes. Hum Reprod 2012;27:33213327. https://doi.org/10.1093/humrep/des280

8. Rudick BJ, Ingles SA, Chung K, Stanczyk FZ, Paulson $R J$, Bendikson KA. Influence of vitamin D levels on in vitro fertilization outcomes in donor-recipient cycles. Fertil Steril 2014;101:447-452. https://doi. org/10.1016/j.fertnstert.2013.10.008

9. Ozkan S, Jindal S, Greenseid K, et al. Replete vitamin D stores predict reproductive success following in vitro fertilization. Fertil Steril 2010;94:1314-1319. https://doi. org/10.1016/j.fertnstert.2009.05.019

10. Zhao J, Huang X, Xu B, Yan Y, Zhang Q, Li Y. Whether vitamin $D$ was associated with clinical outcome after IVF/ICSI: a systematic review and meta-analysis. Reprod Biol Endocrinol 2018;16:13. https://doi. org/10.1186/s12958-018-0324-3

11. Anifandis GM, Dafopoulos $\mathrm{K}$, Messini $\mathrm{Cl}$, et al. Prognostic value of follicular fluid $25-\mathrm{OH}$ vitamin D and glucose levels in the IVF outcome. Reprod Biol Endocrinol 2010;8:91. https://doi.org/10.1186/14777827-8-91

12. Firouzabadi RD, Rahmani E, Rahsepar M, Firouzabadi MM. Value of follicular fluid vitamin $D$ in predicting the pregnancy rate in an IVF program. Arch Gynecol Obstet 2014;289:201-206. https://doi.org/10.1007/ s00404-013-2959-9

13. Franasiak JM, Molinaro TA, Dubell EK, et al. Vitamin D levels do not affect IVF outcomes following the transfer of euploid blastocysts. Am J Obstet Gynecol 2015;212:315.e1-6. https://doi.org/10.1016/j. ajog.2014.09.029

14. Neville G, Martyn F, Kilbane M, et al. Vitamin D status and fertility outcomes during winter among couples undergoing in vitro fertilization/intracytoplasmic sperm injection. Int J Gynaecol Obstet 2016;135:172-176. https://doi.org/10.1016/j.jigo.2016.04.018

15. World health organization. WHO laboratory manual for the examination and processing of human semen. 5th ed. Geneva: World Health Organization; 2010.
16. Türkiye endokrinoloji ve metabolizma derneği. Vitamin D eksikliği. In: Osteoporoz ve metabolik kemik hastalıkları tanı ve tedavi kılavuzu. 14. ed., Ankara: 2019; 119-127. http://temd.org.tr/admin/uploads/tbl_ kilavuz/20190506164125-2019tbl_kilavuz0f7419cd64. pdf. Erişim tarihi 06 Kasım 2020

17. Lerchbaum E, Obermayer Pietsch B. Vitamin D and fertility: a systematic review. Eur J Endocrinol 2012;166:765-778. https://doi.org/10.1530/EJE-110984

18. Lv SS, Wang JY, Wang $X Q$, Wang $Y, X u$ Y. Serum vitamin $D$ status and in vitro fertilization outcomes: a systematic review and meta-analysis. Arch Gynecol Obstet 2016;293:1339-1345. https://doi.org/10.1007/ s00404-016-4058-1

19. Parikh G, Varadinova M, Suwandhi $P$, et al. Vitamin D regulates steroidogenesis and insulin-like growth factor binding protein-1 (IGFBP-1) production in human ovarian cells. Horm Metab Res 2010;42:754-757. https://doi.org/10.1055/s-0030-1262837

20. Yoshizawa $T$, Handa $Y$, Uematsu $Y$, et al. Mice lacking the vitamin $\mathrm{D}$ receptor exhibit impaired bone formation, uterine hypoplasia and growth retardation after weaning. Nat Genet 1997;16:391-396. https://doi. org/10.1038/ng0897-391

21. Liu X, Zhang W, Xu Y, et al. Effect of vitamin D status on normal fertilization rate following in vitro fertilization. Reprod Biol Endocrinol 2019;17:59. https://doi. org/10.1186/s12958-019-0500-0

22. Yilmaz N, Ersoy E, Tokmak A, et al. Do serum vitamin $D$ levels have any effect on intrauterine insemination success? Int J Fertil Steril 2018;12:164-168. https://doi. org/10.22074/ijfs.2018.5256

23. Asadi $M$, Matin $N$, Frootan $M$, Mohamadpour J, Qorbani M, Tanha FD. Vitamin D improves endometrial thickness in PCOS women who need intrauterine insemination: a randomized double-blind placebocontrolled trial. Arch Gynecol Obstet 2014;289:865870. https://doi.org/10.1007/s00404-013-3055-x

Etik kurul onayı: Pamukkale Üniversitesi Tıp Fakültesi Girişimsel Olmayan Klinik Araştırmalar Etik Kurulu'ndan 27.10.2020 tarih ve 20/66549 karar sayısı ile yerel etik onayı alındı.

\section{Yazarların makaleye olan katkıları}

C.K ve Ü.Ç. çalışmanın ana fikrini ve hipotezini kurgulamışlardır. C.K ve Ü.Ç. teoriyi geliştirmiş, gereç ve yöntem bölümünü düzenlemişlerdir. Sonuçlar kısmındaki verilerin değerlendirmesini CK yapmıştır. Makalenin tartışma bölümü C.K ve Ü.Ç. tarafından yazılmıştır. C.K ve Ü.Ç. makaleyi gözden geçirip 
gerekli düzeltmeleri yapmış ve onaylamıştır. Her iki yazar da çalışmanın tamamını tartışmış ve son halini onaylamıştır. 